Отримано: 31 серпня 2018 р.

Прорецензовано: 08 вересня 2018 р.

Прийнято до друку: 17 вересня 2018 р.

e-mail: e.ionin2008@gmail.com

s.s.lavryk@gmail.com

DOI: $10.25264 / 2311-5149-2018-10(38)-60-67$
Іонін Є. Є., Лаврик С. С. Сучасні тіньові схеми конвертаційних центрів: виявлення та попередження. Наукові записки Національного університету «Острозька академія». Серія «Економіка» : науковий журнал. Острог : Вид-во НаУОА, вересень 2018. № 10(38). С. 60-67.

Іонін Євген Свгенович,

доктор економічних наук, професор, завідувач кафедри обліку, аналізу і аудиту, Донецький наиіональний університет імені Василя Стуса

Лаврик Сергій Сергійович,

аспірант, Донеиький національний університет імені Василя Стуса

\title{
СУЧАСНІ ТІНЬОВІ СХЕМИ КОНВЕРТАЦІЙНИХ ЦЕНТРІВ: ВИЯВЛЕННЯ ТА ПОПЕРЕДЖЕННЯ
}

\begin{abstract}
У статті розглянуто визначення поняття «конвертаційний центтр» $i$ «фіктивне підприємство». Проаналізовано динаміку кількості конвертаційних иеентів за останні роки, наведено приблизні збитки від їх діяльності. Встановлено важливу роль банків у тіньових схемах конвертщентрів. Запропоновано рішення попередження діяльності банків у таких схемах. Висвітлено найбільш актуальні схеми легалізаиії коштів, отриманих злочинним шляхом із застосуванням буферних підприємств, зовнішньоекономічних контрактів і кореспондентських рахунків. Досліджено сучасні схеми легалізації «брудних» грочей фізичними особами за допомогою електронних платіжних систем $i$ бірж криптовалюти. За результатами проведеного дослідження було запропоновано основні методи боротьби зі схемами легалізації коштів, щзо отримані нелегально. Наведено використання інструменту банкрутства як захисного засобу конвертаційними центрами й обтрунтовано важливість модернізації служб фінансового моніторингу.

Ключові слова: тіньова економіка, конвертаційний цеентр, фіктивне підприємство, тіньова схема, відмивання
\end{abstract} громей.

\section{Ионин Евгений Евгеньевич,}

доктор экономических наук, профессор, заведующий кафедрой учёта, анализа и аудита, Донеикий начиональный университет имени Васыля Стуса

Лаврик Сергей Сергеевич,

аспирант, Донеикий наџиональный университет имени Васыля Стуса

\section{СОВРЕМЕННЫЕ ТЕНЕВЫЕ СХЕМЫ КОНВЕРТАЦИОННЫХ ЦЕНТРОВ: ВЫЯВЛЕНИЕ И ПРЕДУПРЕЖДЕНИЕ}

В статье рассмотрены определение понятия «конвертационный иеентр» $и$ «фиктивное предприятие». Проанализирована динамика количества конвертационных иеетров за последние годы, приведены примерные убытки от их деятельности. Установлена важная роль банков в теневых схемах конвертиентров. Предложены решения предупреждения деятельности банков в таких схемах. Освещены наиболее актуальные схемы легализации средств, полученных преступным путем с применением буферных предприятий, внешнеэкономических контрактов и корреспондентских счетов. Исследованы современные схемы легализации «грязных» денег физическими лицами с помощью электронных платежных систем и бирж криптовалют. По результатам проведенного исследования были предложены основные методы борьбы со схемами легализации средств, полученных нелегально. Представлено использование инструмента банкротства в качестве защитного средства конвертационными цеентрами и обоснована важность модернизаџии служб финансового мониторинга.

Ключевые слова: теневая экономика, конвертационный иентр, фиктивное предприятие, теневая схема, отмывание денег.

\author{
Yevhen Ionin, \\ Doctor of Economics, Professor, Head of the Department of Accounting, Analysis and Audit, \\ Vasyl' Stus Donetsk National University \\ Sergii Lavryk, \\ postgraduate student, Vasyl' Stus Donetsk National University
}

\section{MODERN SHADOW SCHEMES OF THE CONVERSION CENTERS: IDENTIFICATION AND PREVENTION}

The article considers the definition of a «conversion center» and a «fictitious enterprise». The dynamics of the number of conversion centers in recent years is analyzed, approximate losses from their activities are given. Acknowledgement of banks 
important role in the shadow schemes of conversion centers, made it possible to offer solutions to neutralize banks activities in such schemes. Bank fines are considered in terms of shadow schemes non-disclosure, which implies the ineffectiveness of the intra-bank system to prevent the legalization of criminal proceeds and the financing of terrorism. Special attention was paid to the shadow channels, which in their schemes use transit pits, with detailed consideration of all stages and recommendations for preventing the emergence of such schemes in the future. The article shows the most relevant schemes for legalizing funds obtained by criminal ways with the use of buffer enterprises, foreign economic contracts and correspondent accounts. The modern schemes of "dirty" money legalization by individuals with using electronic payment systems and the cryptocurrency exchange are investigated. Despite the prohibition on certain electronic payment systems in Ukraine, it is concluded that they are still actively used by Ukrainian citizens. It has also been established that significant shadow flows through these systems arise due to low restrictions on anonymous calculations throughout the day, which to a large extent seems to us reveals the fault of the electronic payment systems themselves. The results of the conducted research made it possible to propose the main methods of fighting with schemes legalizing illegally acquired funds. Bankruptcy is shown as a protective tool for conversion centers. The importance of financial monitoring services modernization is justified.

Key words: shadow economy, conversion center, fictitious companies, shadow scheme, money laundering.

Постановка проблеми. Сучасне українське законодавство у сфері фінансів усе ще залишає можливості для існування тіньових схем із використанням податкової мінімізації і найбільш розповсюдженими $\epsilon$ ті, що формально не порушують законів - сірі, однак чималих збитків завдають підприємства, які задіяні в ланках «конвертаційних центрів» або використовують схеми із фіктивністю підприємств. На сьогодні ця проблема досягає загрозливих масштабів, реальні розміри якої було викрито лише після тотального переформатування найвищих ешелонів влади у 2014 р., що також було однією з причин масових протестних акцій.

Фіктивні компанії є невід'ємною частиною майже всіх наявних методів відмивання коштів. Прогалини в законодавстві, корупція та недосконала система фінансового контролю є однією $з$ причин можливості формування неіснуючого податкового кредиту та переводи значних сум у готівку із одночасною іiі легалізацією, що водночас призводить значних збитків у державі й одночасним зростанням масштабів тіньової економіки в Україні.

Не дивлячись на низьку частку фіктивного підприємництва в загальній структурі злочинів, створені від такої діяльності збитки досягають величезних сум, що актуалізує питання вдосконалення механізмів їх відстеження та методів боротьби з ними. Розтрати держмайна, умисне завищення цін, фіктивні тендери, зловживання службовим становищем - усе це є незамінним знаряддям шахраїв у маніпулюванні фінансовими ресурсами.

Аналіз останніх досліджень і публікацій. Питання боротьби з тіньовою економікою досліджували такі видатні зарубіжні і вітчизняні вчені: В. Базилевич, 3. Варналій, О. Ладюк, І. Мазур, Т. Ковальчук, В. Мандибура, Ф. Шнайдер, Г. Абадінскі, Дж. Арвай, Д. Блейдс, П. Гутман. Однак лише деякі із них порушують питання фіктивного підприємництва як вагомої ланки, через яку діють суб'єкти тіньової економіки. Говорячи про боротьбу із конвертаційними центрами і фіктивними підприємствами, частіше за все розглядають саме юридичний бік. У той час як економічні передумови і наслідки цього явища для тіньової економіки й економіки держави загалом залишаються осторонь, окрему увагу щодо питання конверт центрів приділили: В. Навроцький, О. Білоус, А. Римарчук, А. Волобуєв, І. Андрущенко.

Метою статті є дослідження «конвертаційних (конверсійних) центрів, які тісно пов'язані з «відмиванням» коштів і є невід'ємною частиною тіньової економіки з наступним аналізом тіньових схем, за якими вони працюють для з'ясування методу їх роботи та слабких місць із подальшими рекомендаціями щодо попередження виникнення таких структур.

Виклад основного матеріалу. Попри велику кількість наукових робіт, досі не має єдиного точного визначення поняття «конвертаційний центр». У своєму дослідженні О. П. Білоус наголошує на тому, що правильно використовувати все ж «конверсійний центр» [1], з чим ми погоджуємося. Проте в широкій практиці, зокрема державними службами, як, наприклад, Державна фіскальна служба України (ДФСУ), використовують поняття «конвертаційний центр» і «конвертація», зважаючи на це, будемо вважити ці два поняття тотожними.

У вузькому сенсі конвертаційний центр - це організація, яка займається операціями, або їх прикриттям, із незаконного конвертування коштів (відмивання грошей) і ухилення від оподатковування. У більш широкому сенсі під конвертаційним центром мають на увазі мережу (ланцюг) організацій, підприємств, фірм із єдиним центром, які займаються відмиванням грошей, формуванням податкового кредиту, незаконного відшкодування ПДВ із бюджету або переведенням готівки із використанням фіктивних підприємств та банків. У ланцюгу можуть працювати не тільки новостворені фірми «одноденки», але і відносно старі - які працюють на ринку більше одного-двох років. Чим складніша мережа, із великою кількістю конвертацій, перетворень товарів, послуг і коштів, і кількості розпаралелених зв'язків, тим більша ступінь приховування та складність розкриття системи. Конвертаційний центр для своєї діяльності отримує прибуток у розмірі певного відсотка (за даними ДФСУ від 2\% до 12\% [2]) «відмитих» коштів, який може 
варіюватися, залежно від складності «конвертацій», ступеня необхідного нівелювання ризику від виявлення незаконного обігу коштів контролюючими організаціями та кінцевої суми прибутку.

Здебільшого конвертцентри реалізують свої тіньові схеми через фіктивні підприємства. Кримінальний кодекс України (ККУ) визначає фіктивне підприємництво (Ст. 205) як «створення або придбання суб'єктів підприємницької діяльності (юридичних осіб) з метою прикриття незаконної діяльності або здійснення видів діяльності, щодо яких є заборона» [3]. Однак необхідно вказати на те, що Ст. 205 ККУ не охоплює індивідуальну форму фіктивного підприємництва, коли суб'єктом є приватний підприємець, фізична особа без створення юридичної особи. Нерозривно пов'язуючи ці два поняття, оскільки фіктивне підприємництво неможливе без фіктивного підприємства, закон не визначає поняття «фіктивне підприємство» окремо.

Наявні легальні інструменти часто використовують із метою злочинного збагачення завдяки створенню фіктивних компаній із нереальними посадовими особами в них, наприклад, безхатченки або навіть померлі. В результаті здійснюються фіктивні фінансово-господарські операції, що призводить до фіктивізації колосальної частини реального сектора економіки та руйнації економічного базису України на фоні незначних покарань за вчинене.

За даними колишнього Міністерства доходів і зборів України, кількість викритих «конвертаційних центрів» склала: у 2009 р. - 225, 2010 - 172, 2011 - 119, 2012 - 80, 2013 - 59 [4] . I $з$ цього може скластися ілюзія про стійку тенденцію до зменшення чисельності таких злочинних об'єднань. Однак з урахуванням отриманої із тих самих джерел інформації про те, що тільки в м. Києві в 2012 р. було виявлено 15 «конвертаційних центрів», а у 2013 - 16 [4], зазначене, на думку О. Білоус, свідчило лише про приховування справжньої криміногенної обстановки та навмисне викривлення статистичних даних [5]. Висловлюють думку щодо боротьби тільки з непідвласними владним особам конвертаційними центрами, а широке розкриття тіньових схем і структур, лише перерозподіл ринку тіньових послуг і боротьба з конкурентами на цьому ринку. Про це побічно свідчить постійно зростаюче число таких центрів із майже незмінними схемами.

Суб'єкти господарювання з ознаками фіктивності стали основою для створення «конвертаційних (конверсійних) центрів», обіг яких лише за перші 4 місяці 2018 р. склав 5567 млн грн [6], що приблизно 1,2 млрд грн недонадходження до бюджету. За 2017 р. оперативними підрозділами ДФСУ припинено протиправну діяльність 65 конвертаційних центрів, якими було проконвертовано 13,6 млрд грн, а збитки від їх діяльності склали 2,5 млрд грн [7], що порівняно з 2018 р., під час збереження динаміки значно менше.

На сьогодні проблему фіктивних підприємств майже не розглядають із економічного погляду, більшість наукових робіт присвячено саме юридичній стороні питання і прогалинам у законодавстві, що значною мірою правильно, оскільки, крім очевидно злочинних намірів, складний бюрократичний механізм чи постійне змінення законодавства також спонукає до порушення закону і відходу в тінь. Утім, ми впевнені, що існування такої категорії як «фіктивне підприємництво» має потужні економічні передумови. Складність ведення бізнесу в сучасних економічних умовах, збільшення податкового навантаження в окремих позиціях, серед яких акцизний збір, який в умовах низької купівельної спроможності населення веде більшою мірою не до збільшення надходжень до бюджету, а до збільшення контрабанди, тінізації економіки та підробок на відповідних ринках, також недосконале адміністрування податків, інфляція та коливання курсу валют - усе це, на нашу думку, є достатньою умовою для існування фіктивного підприємництва, яке використовують для ухилення від податків, а значить для ефективної боротьби з фіктивним підприємництвом i, як результат, 3 конвертаційними центрами, необхідно використовувати весь наявний інструментарій із боку держави, а не лише юридичний. Одним із таких інструментів може були застосування фінансових важелів економіки.

Для правильного і дієвого застосування таких інструментів необхідно проаналізувати, як саме проводять схему конвертації грошових коштів із виявленням ії слабких місць.

Під час дослідження ми встановили, що одним із найбільших каналів тіньової економіки в розрізі конвертаційних центрів $€$ схема із використанням кореспондентських рахунків. Для таких фірм саме незаконна конвертація $є$ основним засобом отримання злочинного прибутку. Тому, насамперед, розглянемо схему створення і використання такого конвертцентру в декілька етапів, на прикладі таблиці 1. 
Типова схема відмивання коштів у конвертаційних центрах

Таблиияя 1 через кореспондентські рахунки в іноземних банках

\begin{tabular}{|c|c|}
\hline Eтап & Діяльність конвертаційного центру \\
\hline I & $\begin{array}{l}\text { За загубленими (викраденими) паспортами або за незначну винагороду в безхатченків, літніх людей або людей } \\
\text { у скрутному становищі реєструється фіктивна фірма. У «партнерському» комерційному банку за допомогою } \\
\text { цієї фіктивної фірми відкривають розрахунковий і валютний рахунки. } \\
\text { Частіше за все, фіктивні фірми реєструють в одній області, розрахункові рахунки відкривають у банківських } \\
\text { установах іншої області, накопичення коштів (зокрема, шляхом їх розкрадання) відбувається ще в ряді облас- } \\
\text { тей, а переказ коштів через кореспондентські рахунки відповідних банків - взагалі в іншому регіоні. }\end{array}$ \\
\hline II & У банк пред’являють контракт з іноземною фірмою, фіктивну митну декларацію на ввезений в Україну товар. \\
\hline III & $\begin{array}{l}\text { Подають заяву на купівлю уповноваженим банком вільноконвертованої валюти на Українській міжбанківській } \\
\text { валютній біржі. }\end{array}$ \\
\hline IV & $\begin{array}{l}\text { Куплену валюту перераховують за кордон на «свої» рахунки в іноземних банках за фіктивним експортним } \\
\text { контрактом. }\end{array}$ \\
\hline $\mathrm{V}$ & $\begin{array}{l}\text { Отриману валюту переводять у готівку та шляхом контрабанди ввозиться в Україну або залишають на валют- } \\
\text { них рахунках в українських банках. }\end{array}$ \\
\hline
\end{tabular}

Джерело: складено автором на основі [8].

Під час перевірок установ, які підозрюються у фіктивності перше, на що необхідно звернути увагу - це відсутність суб'єкта підприємництва за юридичною адресою та неможливість встановлення місцезнаходження адміністрації суб'єкта підприємництва (директора, головного бухгалтера), якщо фірма підходить під такі ознаки, то з високою долею вірогідності вона є фіктивною [8].

Інколи можна виявити конвертаційний центр через його «буферне підприємство», тобто таке підприємство, що створено бути посередником/прикриттям між суб'єктом, що відмиває кошти і фіктивною компанією (рис. 1). Здійснений аналіз показав, що така організація зазвичай відповідає всім нормам, проходить усі види реєстрації та надає податкову звітність на регулярній основі. Однак діяльність такої компанії мінімальна, а отримання доходу лише документальне - нібито компанія здійснює послуги (за рекламні, маркетингові послуги, інформаційно-довідкове забезпечення), для фіктивної компанії та цільового суб'єкта, або є посередником, що постачає товари. Дослідження дають змогу говорити, що конвертація через схожі до цієї схеми сягають загрозливих масштабів і робить цей тіньовий канал другим за об'ємами. У разі підозри пособництва такого підприємства конверт центру необхідно, насамперед, перевірити реальність виконаних угод і наданих послуг. «Тіньовий» дохід за таку діяльність коливається від 2\% до 4\% від згоди. Такі підприємства акумулюють грошові кошти, що надходять від фіктивних підприємств і які необхідно легалізувати. Така схема дій дозволяє запобігти блокуванню коштів на рахунках фіктивних підприємств.

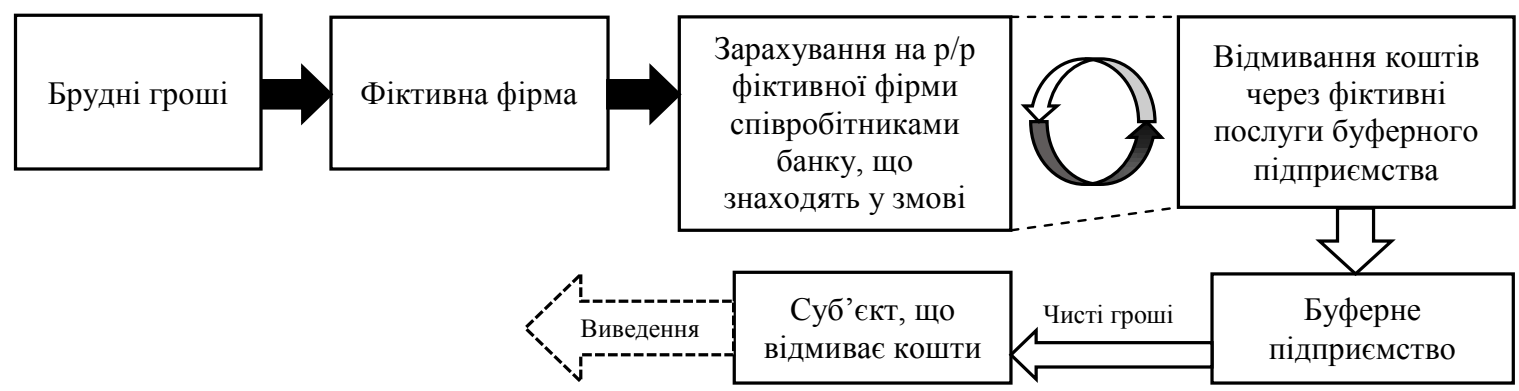

Рис. 1. Схема відмивання коштів через буферні підприсмства

Джерело: складено автором.

Наступне зображення є схематичним відображення різновиду конвертцентру із використанням кореспондентських рахунків, подібно до вказаного в таблиці 1. Іноді грошові кошти, що надходять на адресу фіктивної фірми, зараховуються на розрахунковий рахунок (p/p) співробітниками банків, які знаходяться у змові, лише безпосередньо перед «конвертацією» або взагалі переводять на кореспондентські рахунки іноземних банків за фіктивними зовнішньоекономічними контрактами (рис. 2) [8].

Говорячи про банки в ланці конвертцентру, часто використовують близькі зв'язки зі службовими особами банку, а частіше за все, саме 3 керівниками філій або підрозділів, рідше з вищими керівниками банку або власниками. 


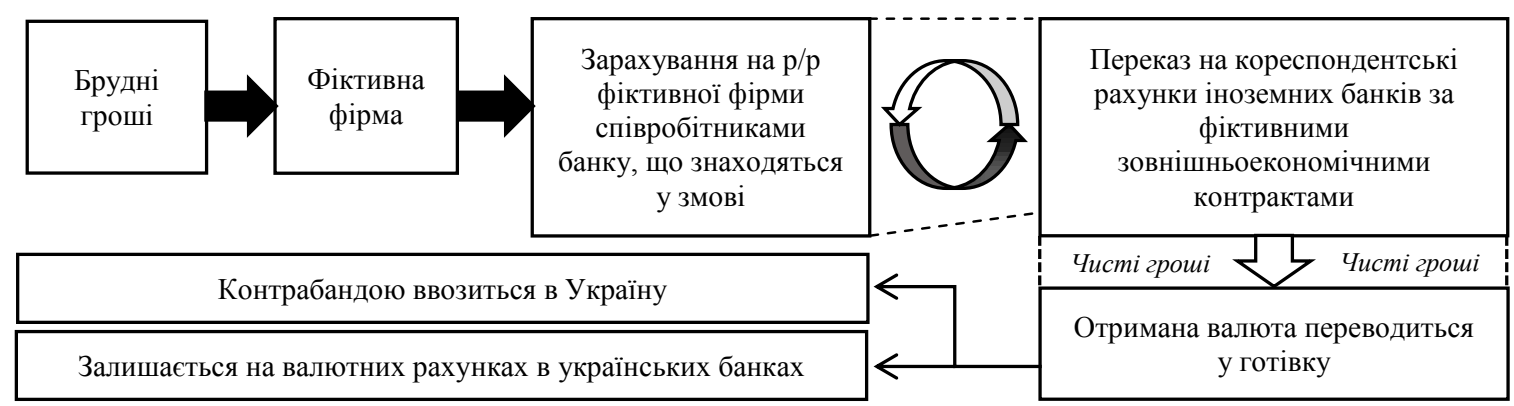

\section{Рис. 2. Схема відмивання коштів через кореспондентські рахунки іноземних банків}

Джерело: складено автором.

3 цього можна зробити висновок, якщо вищий менеджмент банку не знає про таку домовленість, то під час внутрішньої перевірки є можливість викриття фіктивності клієнта й окремих осіб у банку, що сприяли укладанню такої домовленості. Для ефективної внутрішньої перевірки банк повинен використовувати весь наявний сучасний методичний матеріал, це рекомендації FATF, BCBS, Свропейських організацій (AML-директива), що покликані підвищити безпеку банківських установ і рекомендації НБУ.

Ми вважаємо, що з боку НБУ інформація щодо перевірки клієнтів на наявність фінансових операцій з ознаками фіктивності має носити не рекомендаційний характер, а в деяких випадках і примусовий. Надані критерії для виявлення клієнтів, фінансові операції яких містять ознаки фіктивності у листі НБУ від 26.05.2017 р. № 25-0008/37888 «Щодо фінансових операції з ознаками фіктивності» [9] повинні активно впроваджуватися в кожному українському банку. Особливу увагу слід приділяти пунктам: «Керівник належить до соціально вразливих верств населення або є особою, яка зареєстрована на непідконтрольній Україні території», «Період існування клієнта», «Невідповідність ресурсів обсягам здійснюваної діяльності».

Аналіз застосування до банків заходів впливу у вигляді штрафів указує на те, що не зважаючи на щорічне вдосконалення заходів перевірки ризикових клієнтів, кількість випадків ризикової банківської діяльності зростає. За 2017 р. було 9 випадків проведення клієнтами «схемних» операцій у особливо великих обсягах, сумарна кількість штрафів сягнула 37,5 млн грн і 8 випадків не виявлення РЕР («політично значущі особи» (від англ. politically exposed persons) із сумою штрафів на 2,9 млн грн [10], що свідчить про неефективність внутрішньобанківської системи запобігання легалізації кримінальних доходів і фінансування тероризму.

Утім, здебільшого, якщо необхідно отримати готівку, то на рівні малого бізнесу використовують схеми без переведення у валюту або залучення додаткових інструментів банківської системи чи страхових компаній, а шляхом використання послуг «нальщиків», коли фіктивна компанія переказує кошти на карту фізичної особи, а та за якомога швидший термін знімає їх і передає замовнику за винагороду у певний відсоток. Особа, на яку оформлена банківська карта й особа, що знімає кошти - це завжди різні люди, оскільки банківські карти купують на чорному ринку (так звані «дропкарти»), i саме через це протидіяти злочинцям вкрай важко. Нерідко кошти знімають навіть у касах банків під час співпраці співробітників банку, що знаходяться у змові з фіктивним підприємством. Спосіб також варто вважати найбільш розповсюдженим у разі відмивання невеликих доходів отриманих злочинним чи обманним шляхом, однак водночас передують дії із заплутування слідів походження коштів.

Наступну зазначену схему використовують переважно фізичні особи (рис. 3). Однак попередній аналіз показав, що цей напрям швидко розвивається. 3 кожним роком до тіньового каналу залучають усе більшу кількість осіб, а розвиток комп'ютерних технологій дозволяє за найшвидший термін проводити операції відмивання і подальшого переказу. На першому етапі відбувається переказ коштів на крипто-валютні біржі, серед яких: localbitcoins.com, binance.com, bitflip.cc, bitfinex.com, bittrex.com, yobit.io та інші, де на «брудні» гроші купують одну з обраних вільноконвертованих криптовалют, за неї купують іншу криптовалюту (наприклад, Bitcoin - Monero - Bitcoin), процес може повторюватись, залежно від об'єму та походження брудних коштів, чим більше конвертацій, тим складніше відстежити походження таких коштів. Наступний етап - кошти переводять або на згадану дропкарту із наступним їх зняттям у нашій країні, або на іншу біржу для зберігання, чи навіть на одну з електронних платіжних систем (частіше за все PayPal - американські банки або не відповідають на запити вітчизняних правоохоронців, або відповідь буває через довгий проміжок часу, 1-2 місяці). 


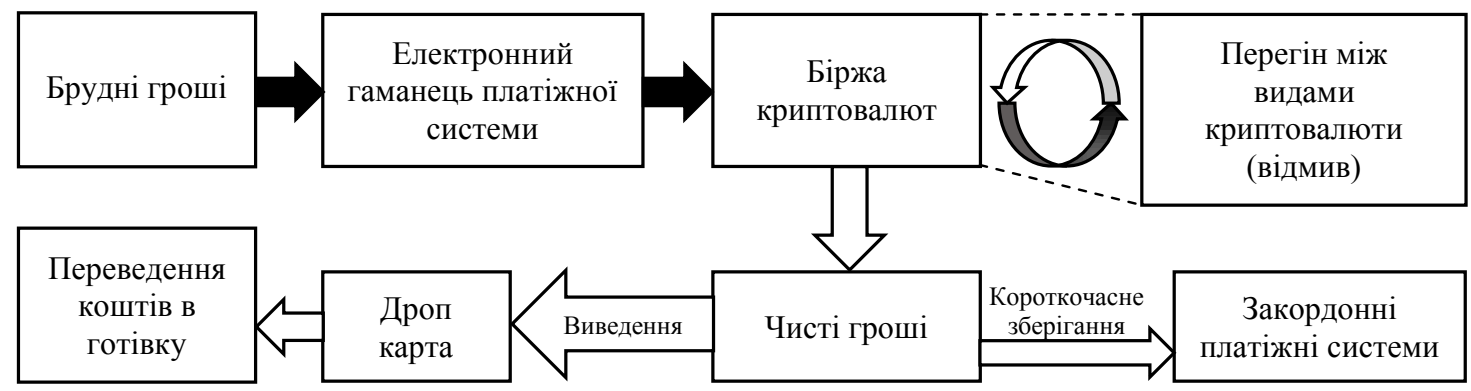

Рис. 3. Схема відмивання брудних грошей через електронні платіжні системи та біржі криптовалют

Джерело: складено автором.

Враховуючи зазначене, у широкому сенсі біржі також можна віднести до різновиду конвертцентрів, незважаючи на те, що «відмив» відбується без відома власників біржі, вони повною мірою виконують функції з відмивання брудних коштів, видаючи їх за дохід, отриманий від торгівлі валютою.

Незважаючи на офіційну заборону на державному рівні деяких російських електронних платіжних систем, громадяни України їх усе одно активно використовують. На практиці блокування цих систем у мережі Інтернет легко долається, а тому ми у своєму дослідженні розглядаємо ці платіжні системи, зокрема найбільш поширені WebMoney, QiWi, Yandex-гроші.

Для того, щоб завести кошти на біржу, часто (але не обов'язково) використовують електронні платіжні системи країн СНД у яких можна вести розрахунки не надаючи водночас особисті дані, частіше за все достатньо електронної пошти чи номера мобільного телефону. Крім того, вказані нижче недоліки характерні і суто українським платіжним системам, серед яких ГлобалМані, ЕasyРay й інші.

При достатній захищеності мережі важко встановити власника електронної скриньки, а сім-карту для телефона в Україні можна придбати без документів, що засвідчують особу. На базових акаунтах (без підтвердження особи) таких платіжних систем стоять обмеження щодо максимальних сум переказів, однак цю заборону легко долають шляхом розбиття суми на менші частини. Наприклад, у відомій системі QiWi, яка хоча офіційно зареєстрована в Росії має популярність у всій СНД, максимальний розмір такого переказу - 15 тисяч рублів, тому суму в 50 або 100 тисяч можна розділити на 4 або 7 платежів.

На нашу думку, обхід такої заборони в електронних системах, що мають електронні гаманці, має критичне значення, оскільки заборона розповсюджується лише на одну операцію і не діє на загальну суму протягом одного дня (якщо це не зовсім великі суми понад 500 тисяч рублів, які відстежуються системою), що, своєю чергою, не дає багато часу для розслідування злочинів, що пов'язані із такими електронними платіжними системами. Ми вбачаємо в цьому злий намір із боку таких систем, які не бажають втрачати додатковий дохід замість підвищення безпеки своєї системи і протидії відмиванню брудних коштів.

Із чого можна зробити висновок, що електронні платіжні системи які мають у функціоналі електронні гаманці, як вітчизняні так і ті, що мають специфіку роботи у країнах СНД, не мають достатнього рівня захищеності від конвертації брудних грошей, на що державні контролюючі установи повинні звернути увагу. Ми можемо надати рекомендації щодо посилення безпеки платіжних систем у частині обов'язкової ідентифікації користувача перед розрахунковими операціями з метою унеможливлення анонімного процесу переказу коштів. Уважаємо, що таке рішення повинно лобіюватись із боку НБУ в Україні, та відповідними органами, які контролюють електронні платіжні системи в інших країнах. Оскільки на разі положення НБУ, яке регулює діяльність небанківських платіжних систем, і вимагає обов'язкової ідентифікації платника стосується лише внутрішньодержавних платіжних систем, чим активно користуються системи, що просувають себе як «міжнародні», то для клієнтів це значний плюс, тобто можливість прямого і анонімного переказу коштів між фізичними особами. Для контролюючих органів та держави - це створює проблеми, тому що, з огляду на обмеження сум платежів готівкою, це дозволяє використовувати їх для обслуговування тіньової економіки.

У разі якщо даний інструмент неможливо застосувати, то встановлення мінімально можливих сум граничних розрахунків на день на анонімних рахунках також $є$ перспективним кроком. На нашу думку, існує потреба у внесенні змін до Закону України «Про банки і банківську діяльність» і в Податковий кодекс із метою формування правових засад протидії злочинам, спрямованим на легалізацію коштів через такі юрисдикції або які можна прирівняти до офшорних.

Середньої складності конвертаційна схема була викрита в Київській області [6]. Дослідження показало, що іiі функціонування було ефективнішим щодо інших, а сумарний об’єм проконвертованих коштів 
сягнув 1 млрд. грн за 2 роки активної фази. Далі податковою міліцією були викриті схожі центри, які працювали за аналогічною схемою. Для аналізу і виявлення слабких місць наведемо схему (рис. 4).

Ліва частина схеми $\epsilon$ взаємодією між клієнтом і транзитною ямою, яка $\epsilon$ мозком конвертаційного центру. Клієнт (реально чинне підприємство) купує товар і перераховує кошти за нього на p/p транзитної ями. Після переведення в готівку фіктивною фірмою, вона повертається до клієнта разом із документальним підтвердженням проведених операцій: договори, податкові та видаткові накладні або акти виконаних робіт на будь-який товар, роботи, послуги тощо - залежно від виду діяльності конкретної фіктивної фірми. Такі фінансово-господарські операції є правомірними і проходять у податкових деклараціях на додану вартість, які щомісяця подаються в органи ДФС. На отриману готівку клієнт купує тіньовий товар чи послуги за значно меншою ціною, а дохід від продажу надходить на власний рахунок від замовника, або таку готівку можуть використовувати для видачі заробітних плат у конвертах.

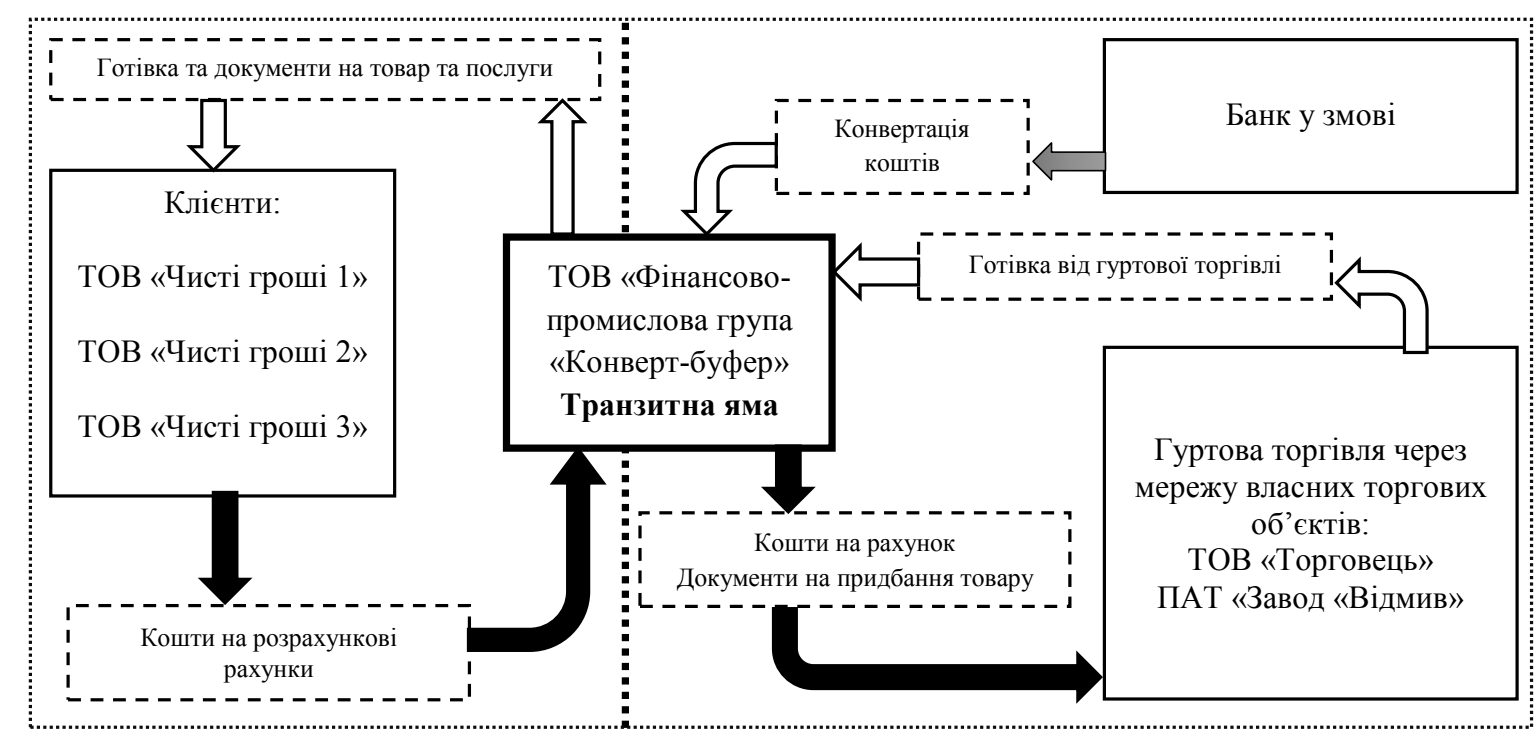

Рис. 4. Тіньова схема переведення коштів у готівку із використанням транзитних ям

Джерело: складено автором.

Права частина схеми дає нам зрозуміти як саме здійснюється трансфер у готівку. На відміну від описаних вище схем із прямим виводом у готівку з банківських рахунків, щоб не потрапити в поле зору фінансового моніторингу ця схема характерна використанням діючих фірм-гуртівень [11], фірм-імпортерів, що спеціалізуються на торгівлі товарами, значна зміна цін на які не викликає підозр, що можна виокремити в окрему субсхему ухилення від сплати податків. Конвертцентр нібито купує товар у підприємств гуртової торгівлі за значно заниженою від реальної ціною, а вони, своєю чергою, реалізують товари за максимально можливу ціну у своїх торгових точках чи на ринку, а отриману готівку за реалізовану продукцію офіційно відображають у бухгалтерському та податковому обліку. У результаті такої роботи до центру повертається сума, але вже готівкою разом із відповідними документами для податкової на придбання продукції за нижчою ціною, а «гуртівня» отримує дохід від завищеної ціни на товар. Більшість дослідників зупиняються на тому, що такі схеми не можуть вільно існувати без відповідного втручання 3 боку корумпованих співробітників ДФС, податкової міліції чи депутатів.

Після відпрацювання свого терміну організація декларує порожні графи у звітах, а фіктивні компанії переходять на так званий «етап прийняття боргів», а їх діяльність по декларації не здійснюється. Транзитна яма, як і фіктивні компанії, змінює власника і переводить своїх клієнтів на нову організацію, крім того - приймає на p/p у банку борги від реальних суб'єктів, які задекларували та сформували собі витрати і кредит за виписаними документами, однак не встигли перерахувати кошти, тобто конвертувати ï у готівку. Таким чином, фірма готується до закриття або банкрутства, щоб забезпечити безпеку для клієнтів із боку перевіряючих організацій [8].

Слід зупинити увагу на використанні інструменту банкрутства як захисного засобу конвертаційних центрів - підприємство, що визнає себе банкрутом, варто перевіряти в розрізі причетності до фіктивних підприємств і здійснених операцій на предмет їх фіктивності, а саме: купівля, продаж товарів, послуг за значно вищими або нижчими цінами від ринкових на регулярній основі, за чим можна звернутися до динаміки цін (тарифів) на споживчому ринку Держстату, а раніше за даними Державної інспекції 3 контролю за цінами щодо середньоринкових оптово-відпускних і роздрібних цін [12]. 
Вищесказане також передбачає важливість адаптації Державної служби фінансового моніторингу на відстеження руху коштів на щойно відкритих рахунках і запровадження критеріїв градації банківських клієнтів щодо ризику участі в тіньових схемах спрямованих на легалізацію коштів, здобутих злочинним шляхом, зокрема у складі конвертаційного центру.

Висновки. Отже, підбиваючи підсумки, можна сказати, що проблема конвертаційних центрів в Україні у 2018 р. постає як ніколи гостро. Держава отримує від їх діяльності значні збитки, а виявлення і знешкодження $з$ боку ДФСУ проходить надто вільно і не в повному обсязі. Крім того, часто страждає підприємець, який не був причетний до діяльності пов'язаної із відмиванням коштів, що вимагає від нас надалі покращувати методи боротьби з фіктивними компаніями у складі конвертцентрів. Аналіз тіньових схем із відмивання коштів отриманих злочинним шляхом показав, що більшість із них неможлива без тісної співучасті банку, а тому менеджмент банку і головного регулятора повинні звернути увагу на застосування в повному обсязі методології та кроків попередження ризиків, що пропонуються європейськими партнерами та носити примусовий характер стосовно деяких категорій клієнтів. Проаналізовані новітні схеми відмивання грошей із використанням мережі Інтернет і бірж, зокрема бірж криптовалют, ми вважаємо, що цей напрям тіньових схем швидко розвивається та невдовзі також може сягнути великих масштабів, у зв'язку з чим необхідне подальше дослідження цього питання.

\section{Лiтература:}

1. Білоус О. П. Проблеми визначення поняття «конвертаційний центр». Питання боротьби зі злочинністю : До 20-річчя НАПрН України : зб. наук. пр. Харків, 2013. Вип. 25. С. 197-208. URL: http://dspace.nlu.edu.ua/ handle/123456789/10500.

2. У Києві ліквідовано конвертаційний центр з обігом більше 120 млн. грн. Сайт територіального органу ДФС у м. Києві. 2018. 5 травня. URL: http://kyiv.sfs.gov.ua/media-ark/news-ark/337031.html (дата звернення: 02.06.2018).

3. Кримінальний кодекс України: Документ 2341-III, чинний, редакція від 28.08.2018, підстава 2475-VIII // База даних «Законодавство України» / ВР України. URL:http://zakon2.rada.gov.ua/laws/show/2341-14/page6 (дата звернення: 25.08.2018).

4. Оприлюднено Публічний звіт про діяльність Міндоходів у 2013 році URL: http://minrd.gov.ua/anonsi/5771 .html (дата звернення: 17.09.2017).

5. Білоус О. П. Криміналістичні проблеми протидії «конвертаційним центрам». Криміналістика та судова експертиза: наука, навчання, практика : зб. наук. пр. : у 2 m. - Харків, 2014. - T. 1. - C. 178-195. URL: http:// dspace.nlu.edu.ua/handle/123456789/7093.

6. Оперативні новини. Державна фіскальна служба Украӥни, офіційний портал. дата оновлення: 09.09.2018. URL: http://sfs.gov.ua/media-tsentr/operativni-novini (дата звернення: 02.06.2018).

7. Звіт Державної фіскальної служби України за 2017 рік. Державна фіскальна служба Украӥни, офіційний портал. URL: http://sfs.gov.ua/data/files/223549.PDF (дата звернення: 28.07.2018).

8. Аркуша Л.І. Конвертаційні центри як спосіб легалізації доходів, одержаних у результаті оранізованої злочинної діяльності. Актуальні проблеми держави і права: збірник наукових пращь. Вип. 57 / редкол.: С. В. Ківалов (голов. ред.) та ін.; відп. за вип. В.М. Дрьомін. - Одеса: Юридична література, 2011. - С. 464-472. URL: http://inter.criminology.onua.edu.ua/?p=4147 (дата звернення: 14.09.2018).

9. Національний банк України, лист: «Щодо фінансових операції з ознаками фіктивності», документ v7888500-17, редакція від 26.05.2017. База даних «Законодавство Украӥни» / ВP України. URL: http://zakon3. rada.gov.ua/laws/show/v7888500-17 (дата звернення: 07.06.2018).

10. Береза I. В. Ризик-орієнтований підхід як ефективний метод протидії відмиванню доходів, одержаних злочинним шляхом. Національний банк Украӥні, офіційний портал, Київ, 27 листопада 2017 p. URL: https:// bank.gov.ua/doccatalog/document?id=59678320 (дата звернення: 05.09.2018).

11. Фантомний бізнес конвертаційних центрів / Інформаційне агентство ZIK. 2018 р. 7 грудня. URL: https:// zik.ua/news/2015/12/07/fantomnyy_biznes_konvertatsiynyh_651673 (дата звернення: 10.09.2018).

12. Динаміка цін (тарифів) на споживчому ринку. Держсавна служба статистики, урядовий портал URL: http://www.ukrstat.gov.ua/operativ/operativ2015/ct/mon_c/mon_c.htm (дата звернення: 27.08.2018). 